\title{
Microbial inoculants produced from solid waste compost for bioremediation of diesel-contaminated soils
}

Inoculantes microbianos produzidos a partir de composto de lixo sólido para

biorremediação de solos contaminados com óleo diesel

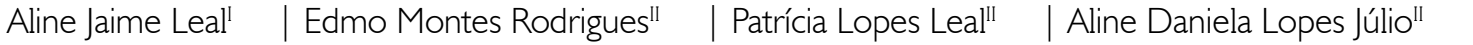 \\ Rita de Cássia Rocha Fernandes" (1) | Arnaldo Chaer Borges" (1) | Marcos Rogério Tótola" (1) \\ Instituto Federal do Rio Grande do Sul. Bagé, Rio Grande do Sul, Brasil \\ "Universidade Federal de Viçosa. Viçosa, Minas Gerais, Brasil
}

\begin{abstract}
Microbial activity can be stimulated to remove soil hydrocarbons after the introduction of hydrocarbonoclastic microorganisms on the environment. We developed microbial inoculants produced from municipal solid waste compost (MSWC) for the bioremediation of diesel-contaminated soils. Diesel application occurred every 4 days for inoculant A and every 8 days for inoculant B. Respirometric analysis, total heterotrophic bacteria count, and evaluation of residual total petroleum hydrocarbons (TPH) were performed. The inoculants were evaluated immediately after production and after storage either at room temperature or under refrigeration. The degradation of TPH after 20 days was greatest at $30 \mathrm{~g} / \mathrm{kg}$. At this concentration, biodegradation of TPH ranged from 98.3 to $99.4 \%$. After storage, efficiency of inoculant $\mathrm{A}$ reached TPH degradation rates of $96.5 \%$ (room temperature) and $98.1 \%$ (refrigeration). Inoculant B showed significant decrease of efficiency after storage, especially at room temperature. The addition of inoculants significantly increased the density of culturable bacteria in soil contaminated with diesel, even after storage. The use of MSWC at a dose of $30 \mathrm{~g} / \mathrm{kg}$ was an effective strategy for the bioremediation of soils contaminated with diesel, allowing the elimination of more than $99 \%$ of the contaminants in 20 days.
\end{abstract}

Keywords: Bioremediation. Hydrocarbonoclastic populations. Soil contamination.

Resumo: A atividade microbiana pode ser estimulada a promover a remoção de hidrocarbonetos no solo ao se introduzir microrganismos hidrocarbonoclásticos. Inoculantes microbianos foram produzidos utilizando-se composto de lixo sólido municipal (CLSM) para a biorremediação de solos contaminados com óleo diesel. A aplicação de diesel ocorreu a cada quatro dias para o inoculante $A$ e a cada oito para o inoculante B. Análises respirométricas, contagem de bactérias heterotróficas totais e avaliação de hidrocarbonetos totais do petróleo (HTP) foram realizadas. Os inoculantes foram avaliados imediatamente após a produção e o armazenamento, à temperatura ambiente e sob refrigeração. A degradação de HTP após 20 dias foi maior na concentração de $30 \mathrm{~g} / \mathrm{kg}$. Nesta concentração, a biodegradação de HTP permaneceu entre 98,3 e 99,4\%. Após armazenamento, a eficiência do inoculante A foi de 96,5\% de degradação (temperatura ambiente) e 98,1\% (sob refrigeração). O inoculante B apresentou significativa redução de eficiência após armazenamento, especialmente à temperatura ambiente. A adição de inoculantes aumentou significativamente a densidade de bactérias cultiváveis no solo contaminado com diesel, mesmo após armazenamento. O uso de CLSM na dose de $30 \mathrm{~g} / \mathrm{kg}$ foi uma estratégia efetiva para a biorremediação de solos contaminados com diesel, permitindo a eliminação de mais de $99 \%$ dos contaminantes em 20 dias.

Palavras-chave: Biorremediação. Populações hidrocarbonoclásticas. Contaminação do solo.

LEAL, A. J., E. M. RODRIGUES, P. L. LEAL, A. D. L. JÚLIO, R. C. R. FERNANDES, A. C. BORGES \& M. R. TÓTOLA, 2019. Microbial inoculants produced from solid waste compost for bioremediation of diesel-contaminated soils. Boletim do Museu Paraense Emílio Goeldi. Ciências Naturais 14(2): 233-244.

Autor para correspondência: Edmo Montes Rodrigues. Universidade Federal de Viçosa. Departamento de Microbiologia. Laboratório de Biotecnologia e Biodiversidade para o Meio Ambiente. Av. P. H. Rolfs, s/n - Centro. Viçosa, MG, Brasil. CEP 36570-900 (edmomontes@ yahoo.com.br).

Recebido em 09/06/2018

Aprovado em 16/01/2019

Responsabilidade editorial: Fernando da Silva Carvalho Filho
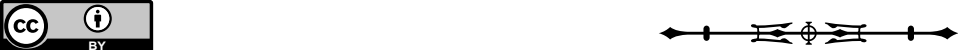


\section{INTRODUCTION}

Soil contamination with petroleum hydrocarbons is a serious environmental problem (Sutton et al., 2013; Aller et al., 2014; Baruah et al., 2014; Sun et al., 2018), caused by accidents during oil extraction, transportation, refining or storage (Lin \& Mendelssohn, 2012; Mosaed et al., 2015). The recovery of hydrocarbon-contaminated environments has been intensively studied and diverse technologies have emerged to overcome the increasing number of contaminated sites (Gogoi et al., 2003; Gordon et al., 2015; Mosaed et al., 2015; Rodrigues \& Tótola, 2015; Júlio et al., 2018).

Petroleum derivatives such as diesel oil are of great economic importance. Accidental releases of these derivatives due to faults in underground storage tanks are a common cause of contamination of soil and groundwater in Brazil (Bento et al., 2003; Mariano et al., 2007; Vieira et al., 2007; Colla et al., 2014). In this type of accident, the remediation of soil is very important to prevent contamination of the water table and to promote the recovery of the soil's ecological functions.

Bioremediation techniques are used to accelerate the biodegradation of contaminants and the rehabilitation of the contaminated environment (Roling et al., 2002; Stroud et al., 2007; Minai-Tehrani et al., 2015), and include biostimulation (improvement of environmental conditions to stimulate microbial activity) (Gallego et al., 2001; Ruberto et al., 2009; Abed et al., 2015; Júlio et al., 2018); bioaugmentation (inoculation of the contaminated site with selected microbial populations efficient in biodegradation of the target contaminant which is generally accompanied by biostimulation) (Straube et al., 1999; Wu et al., 2008; Hassanshahian et al., 2014; Mao et al., 2015); and application of biosurfactants or biosurfactant-producing microorganisms to increase bioavailability of hydrophobic contaminants (Chang et al., 2015; Mao et al., 2015; Rodrigues et al., 2015a).

Biostimulation is adopted when indigenous microorganisms have the potential to degrade the contaminants, but their activity is limited by environmental factors (water activity, $\mathrm{pH}$, mineral nutrients availability, electron acceptors, among others). However, bioaugmentation strategy may be necessary when the indigenous microorganisms cannot metabolize the contaminants or when efficient indigenous populations have been eliminated by toxic effects of the contaminants (Vogel, 1996; Aburto-Medina et al., 2015).

The survival and activity of introduced microorganisms in the soil depends on their adaptation to biotic and abiotic factors of the environment (Fantroussi \& Agathos, 2005; Aburto-Medina et al., 2015; Adams et al., 2015). The selection of contaminant-degrading microorganisms is the critical step in bioaugmentation (Adams et al., 2015; Rodrigues et al., 2015b). When using culture media for the isolation of microorganisms with biodegradation potential of specific contaminants, only cultivable cells are selected. The use of enrichment methods which preserve noncultivable microorganisms may be important to expand the biodegradation potential of microbial inoculums, since these members of microbial communities may also be involved in in hydrocarbon biodegradation (Zhang et al., 2012; Leal et al., 2018). Furthermore, in bioaugmentation, the use of mixed cultures offers some advantages over pure cultures, including higher biodegradative capacity both quantitatively and qualitatively (higher range of contaminants used as substrates for microbial growth); greater resistance to toxic substances; increased potential for establishment of positive microbial interactions (e.g., syntrophy, commensalism, cometabolism) that may increase biodegradation efficiency and survival of the consortium. In addition, the use of consortia with high microbial diversity and functional redundancy increases the chances of survival of populations with the potential for biodegradation of the target contaminants when the inoculant is applied to sites with contrasting characteristics. Taking in consideration the advantages of microbial consortia for use in bioaugmentation, the objective of this study was to evaluate the effectiveness of microbial inoculants produced upon enrichment of hydrocarbonoclastic microbial populations in municipal solid waste compost (MSWC) for bioremediation of diesel-contaminated soil. 


\section{MATERIAL AND METHODS}

\section{MICROBIAL INOCULANTS}

MSWC was enriched in hydrocarbonoclastic populations upon amendment with mineral nutrients: Nitrogen $(N)$, Phosphorous (P), and Potassium (K); and diesel (50 mL/kg at each application). The compost was sieved through a 5-mm mesh sieve and C:N:P ratio was set at 100:10:2 (additional carbon added as hydrocarbons was considered in calculations). Diesel application occurred every 4 days for inoculant $A$ and every 8 days for inoculant $B$, while inoculant $\mathrm{MSWC}_{\mathrm{f}}$ did not receive diesel application, but received the same doses of mineral nutrients (") stands for "fertilized MSWC"). The moisture content was corrected to $60 \%$ of water holding capacity (WHC). Subsequent moisture adjustments were performed when the water content reached $40 \%$ of the WHC, so as to maintain the variation between $40 \%$ and $60 \%$ of the WHC throughout the incubation period (24 days). Each treatment was conducted with three replicates.

\section{SOIL CHARACTERIZATION AND CONTAMINATION}

The soil was sieved through a 5-mm mesh sieve and analyzed for texture and fertility (Table 1). Texture analysis identified the soil as a heavy clay soil. After adjusting the moisture content to $60 \%$ of the WHC, the soil was fertilized with ammonium sulphate and di-potassium phosphate, at a ratio sufficient to obtain the final C:N:P ratio of 100:10:2. Finally, $20 \mathrm{~mL} / \mathrm{kg}$ dry weight of diesel was applied to the soil.

\section{DOSE OF INOCULANTS}

The inoculants were applied to the diesel-contaminated soil in the proportions of 10,30 , or $50 \mathrm{~g} / \mathrm{kg}$ dry mass $\gamma$ ray sterilized compost (25 Mrad) was supplemented to the 10 and $30 \mathrm{~g} / \mathrm{kg}$ treatments ( $40 \mathrm{~g} / \mathrm{kg}$ and $20 \mathrm{~g} / \mathrm{kg}$, respectively), in order to maintain the same proportion of organic matter across all samples.

Each inoculant was added to $60 \mathrm{~g}$ of dieselcontaminated soil. Three control treatments were included: i) soil without inoculants; ii) soil with sterile MSWC only; and iii) sterile soil with sterile MSWC.

The experiment was conducted with three replicates for each treatment, totaling 36 plots. Each plot consisted of a $750 \mathrm{~mL}$ respirometric flask connected to a respirometer equipped with an infrared $\mathrm{CO}_{2}$ detector with intermittent air flow (Sable System, NE, USA). $\mathrm{CO}_{2}$ emission was accompanied for $486 \mathrm{~h}$ at room temperature ranging from $19^{\circ} \mathrm{C}$ to $30^{\circ} \mathrm{C}$ (Table 2 ).

Table 1. Physical and chemical characteristics of the experimental soil. Legends: $\mathrm{WHC}=$ water holding capacity; $\operatorname{Org} \mathrm{C}=$ organic carbon; $\mathrm{cmol}_{c}=$ cent mol of charge.

\begin{tabular}{c|c|c}
\hline Characteristics & Unit & Value \\
\hline Coarse sand & $\%$ & 12 \\
\hline Fine sand & $\%$ & 11 \\
\hline Silt & $\%$ & 4 \\
\hline Clay & $\%$ & 73 \\
\hline $\mathrm{pH}\left(\mathrm{H}_{2} \mathrm{O}\right)$ & $\mathrm{pH}$ unity & 4.8 \\
\hline $\mathrm{WHC}$ & $\%$ & 48.89 \\
\hline Org C & $\mathrm{g} / \mathrm{kg}$ & 32.0 \\
\hline $\mathrm{N} \mathrm{total}$ & $\mathrm{g} / \mathrm{kg}$ & 0.6 \\
\hline $\mathrm{P}$ & $\mathrm{mg} / \mathrm{dm}^{3}$ & 0.5 \\
\hline $\mathrm{K}$ & $\mathrm{mg} / \mathrm{dm}^{3}$ & 39 \\
\hline $\mathrm{Ca}^{2+}$ & $\mathrm{cmol} / \mathrm{dm}^{3}$ & 0.33 \\
\hline $\mathrm{Mg}^{2+}$ & $\mathrm{cmol} / \mathrm{dm}^{3}$ & 0.01 \\
\hline $\mathrm{Al}^{3+}$ & $\mathrm{cmol} / \mathrm{dm}^{3}$ & 0.77 \\
\hline
\end{tabular}

Table 2. Treatments submitted to respirometric assay for determining the appropriate concentration of inoculants to be added to dieselcontaminated soil.

\begin{tabular}{c|c}
\hline Treatment & Inoculum concentrations \\
\hline Inoculant A & 10,30 or $50 \mathrm{~g} / \mathrm{kg}$ \\
\hline Inoculant B $^{\text {MSWC }}$ & 10,30 or $50 \mathrm{~g} / \mathrm{kg}$ \\
\hline Soil (Control) & 10,30 or $50 \mathrm{~g} / \mathrm{kg}$ \\
\hline Sterilised MSWC + Soil (SC+S) & 0 \\
\hline $\begin{array}{c}\text { Sterilised MSWC + Sterilised Soil } \\
\text { (SC+SS) }\end{array}$ & $50 \mathrm{~g} / \mathrm{kg}$ \\
\hline
\end{tabular}




\section{EFFECT OF TEMPERATURE ON THE CONSERVATION OF INOCULANTS}

The inoculants were stored at room temperature or under refrigeration $\left(6-8^{\circ} \mathrm{C}\right)$ in plastic bags. After 97 days, density of heterotrophic bacteria was estimated as previously described. Respirometric assays were performed using $30 \mathrm{~g}$ of inoculants per kg dry weight of diesel-contaminated soil (20 mL/kg dry weight). A non-inoculated treatment was included as control. Each treatment was replicated three times in a completely randomized design. Enumeration of cultivable heterotrophic bacteria and residual TPH in soil were also performed at the end of the respirometric assay (486 h).

\section{ENUMERATION OF CULTIVABLE BACTERIAL POPULATIONS}

Density of cultivable heterotrophic bacteria was assessed by plating serial dilutions (in sodium pyrophosphate $1 \mathrm{~g} / \mathrm{L}$ ) on nutrient agar (Himedia $\left.{ }^{\circledR}\right)$. To inhibit fungal growth, cycloheximide was added $(100 \mathrm{mg} / \mathrm{L})$ to the medium. The plates were incubated at $30^{\circ} \mathrm{C}$ for $24 \mathrm{~h}$ and the bacterial colonies were counted.

\section{CHROMATOGRAPHIC ANALYSIS}

The extraction of TPH from diesel-contaminated soil was performed in a Soxhlet extractor, as per the 3540C method (USEPA, 1996) using $2 \mathrm{~g}$ of soil and $200 \mathrm{~mL}$ of hexane:acetone (1:1). Extraction period was $6 \mathrm{~h}$. The extracts were analyzed by gas chromatograph (QP 5000) coupled to a mass spectrometer (Shimadzu, Model 17-A) using a fused silica capillary column DB-1 (30 $\mathrm{m} \times 0.25 \mathrm{~mm}$ $\times 0.25 \mu \mathrm{m})$ under the following conditions: initial temperature $40^{\circ} \mathrm{C}(2 \mathrm{~min})$, heating ramp of $8-240^{\circ} \mathrm{C} / \mathrm{min}$. The injector temperature was maintained at $260{ }^{\circ} \mathrm{C}$ and detector temperature at $280^{\circ} \mathrm{C}$. Helium was used as the carrier gas at a flow rate of $1 \mathrm{~mL} / \mathrm{min}$ in a splitless injection mode. The TPH degradation percentage was obtained subtracting residual TPH after the respirometric assays from $\mathrm{TPH}$ concentration at time zero.

\section{STATISTICAL ANALYSIS}

All data were tested for normality. After this, the Tukey a posteriori test was employed using SigmaPlot 11.0 software, and $p$ values $<0.05$ were considered significant.

\section{RESULTS}

\section{EFFECT OF INOCULANT DOSE ON HYDROCARBON BIODEGRADATION}

Analyzing the $\mathrm{CO}_{2}$ emission by diesel-contaminated soil, there was an effect of the type of inoculant on $\mathrm{CO}_{2}$ emission (Figure 1). Treatments with inoculants $A$ and $\mathrm{B}$ had higher $\mathrm{CO}_{2}$ emissions than treatments with inoculant $\mathrm{MSWC}_{\mathrm{f}}$ or the treatment without the addition of inoculants during the initial phase (at around 330 hours) (Figure 1). After this phase, the cumulative $\mathrm{CO}_{2}$ emission was equal among the non-inoculated soil and soil inoculated with inoculants $A$ and $B$. The lower $\mathrm{CO}_{2}$ emission by treatments with MSWC $_{f}$ was maintained throughout the experiment (Figure 1).

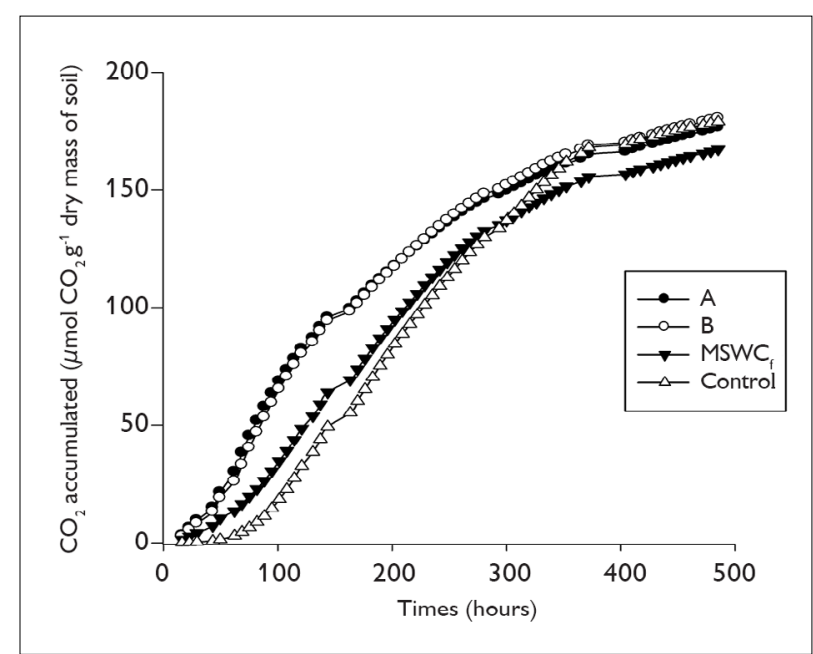

Figure 1. $\mathrm{CO}_{2}$ emission by diesel-contaminated soil ( $\left.20 \mathrm{mg} / \mathrm{kg}\right)$. Noninoculated treatment (control) was used as the control. Inoculants $A$ and $B$ were enriched in hydrocarbonoclastic bacteria upon amendment of $\mathrm{N}$ - and P-fertilized MSWC with diesel $(50 \mathrm{~mL} / \mathrm{kg}$ at each application) every $4^{\text {th }}$ (inoculant A) or $8^{\text {th }}$ day (inoculant B) during 24 days. $M_{S W C}$ received only mineral nutrients at the onset of inoculant production. The data refers to the treatments with $50 \mathrm{~g} / \mathrm{kg}$ of inoculants.

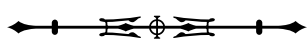


The inoculated soil showed higher density of cultivable heterotrophic bacteria than the noninoculated control, independently of the type of inoculant (Figure 2). For any dose of inoculants, the highest density of cultivable heterotrophic bacteria was obtained in soil inoculated with inoculant $M_{S W C}$. The highest cell densities in treatments with inoculants $A$ and $M S_{F}$ were obtained with $10 \mathrm{~g} / \mathrm{kg}$ of the inoculants, while for treatments with inoculant $B$, the highest cell densities were obtained at $30 \mathrm{~g} / \mathrm{kg}$.

The residual TPH concentration revealed the existence of interactions between the type and dose of inoculants applied to the experimental soil. TPH degradation varied from $84.84 \%$ in the non-inoculated control to $>99 \%$ in some inoculated treatments in only 486 hours (24.25 days). The higher degradation of TPH was obtained in the treatments with $30 \mathrm{~g} / \mathrm{kg}$ of inoculant, irrespective of the type of inoculant (Table 3). At the dose of $50 \mathrm{~g} / \mathrm{kg}$, TPH degradation in the soil inoculated with inoculants $A$ and $B$ was higher than in treatments with inoculant $\mathrm{MSWC}_{\mathrm{f}}$ (Table 3). The dose of the inoculants had significant effect on TPH degradation, except the dose of 10 and $30 \mathrm{~g} / \mathrm{kg}$ of inoculant B. Irrespective of the inoculants used, the dose of $50 \mathrm{~g} / \mathrm{kg}$ resulted in the lowest TPH degradation. The TPH degradation in inoculated treatments was greater than in non-inoculated treatment, irrespective of the inoculant and dose used (Table 3).

\section{EFFECT OF STORAGE ON THE INOCULANTS}

Storage of inoculants under refrigeration was found to be the most suitable for maintaining the viability of the bacterial populations in the inoculants (Figure 3). Inoculants that were supplemented with diesel (inoculants A and B) showed higher bacterial counts than $\mathrm{MSWC}_{\mathrm{f}^{\prime}}$ Cell densities of heterotrophic bacteria was proportional to the amount of diesel added to MSWC (cell densities: Inoculant A > B $>M_{\text {SWC }}$ ). The bacterial count of inoculant $A$ stored under refrigeration remained close to that obtained immediately after its production.

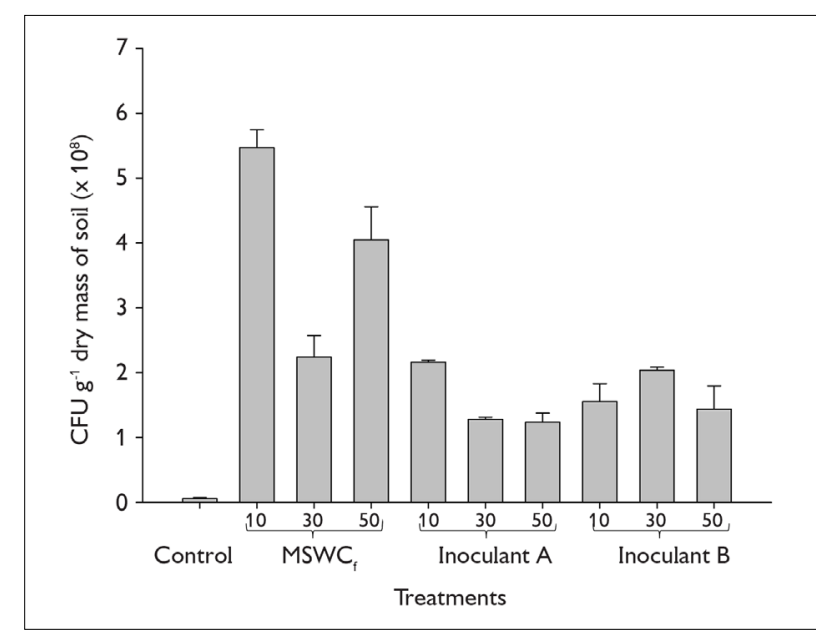

Figure 2. Heterotrophic bacteria in diesel-contaminated soil $(20 \mathrm{~mL} / \mathrm{kg})$. Non-inoculated soil (control) did not receive application of inoculants or MSWC. Inoculants A and B were enriched in hydrocarbonoclastic bacteria upon amendment of $\mathrm{N}$ - and $\mathrm{P}$-fertilized MSWC with diesel ( $50 \mathrm{~mL} / \mathrm{kg}$ at each application) every $4^{\text {th }}$ (inoculant A) or $8^{\text {th }}$ day (inoculant B) during 24 days. $\mathrm{MSWC}_{\mathrm{f}}$ received only mineral nutrients at the onset of inoculant production. The numbers above curly brackets represent the doses of inoculants $(10,30$, or $50 \mathrm{~g} / \mathrm{kg}$ ). The data refers to samples collected at the end of the incubation period in the respirometric assay (486 hours).

Table 3. Percentage of total petroleum hydrocarbon (TPH) degradation in diesel-contaminated soil $(20 \mathrm{~mL} / \mathrm{kg})$ in response to the application of inoculants formulated from municipal solid waste compost (MSWC). The soil received application of inoculants $A$, $\mathrm{B}$, or $\mathrm{MSWC}_{\mathrm{f}}$ in different doses $(10,30$, or $50 \mathrm{~g} / \mathrm{kg})$. In treatments with 0 (control), 10, and $30 \mathrm{~g} / \mathrm{kg}$ of inoculants, gamma-sterilized MSWC $_{f}$ was added to compensate for the lower amount of compost, compared to the treatment with $50 \mathrm{~g} / \mathrm{kg}$. Treatment means followed by the same capital letter, in lines, and lowercase letters, in columns (comparison among columns only), do not differ at $5 \%$ probability by Tukey's test. Inoculants $A$ and $B$ were enriched in hydrocarbonoclastic bacteria upon amendment of $\mathrm{N}$ and P-fertilized MSWC with diesel $(50 \mathrm{~mL} / \mathrm{kg}$ at each application) every $4^{\text {th }}$ (inoculant A) or $8^{\text {th }}$ day (inoculant B) during 24 days. $M \mathrm{SW}_{\mathrm{f}}$ received only mineral nutrients at the onset of inoculant production. Percentage of TPH degradation in non-inoculated soil (control) was $84.84 \%$.

\begin{tabular}{c|c|c|c}
\hline Concentration & Inoculant A & Inoculant B & MSWC $_{f}$ \\
\hline $10 \mathrm{~g} / \mathrm{kg}$ & $\begin{array}{c}96.86 \pm 1.23 \\
\mathrm{Xx}\end{array}$ & $\begin{array}{c}99.00 \pm 0.55 \\
\mathrm{Ww}\end{array}$ & $\begin{array}{c}96.01 \pm 0.17 \\
\mathrm{Xx}\end{array}$ \\
\hline $30 \mathrm{~g} / \mathrm{kg}$ & $\begin{array}{c}98.32 \pm 0.67 \\
\mathrm{Ww}\end{array}$ & $\begin{array}{c}99.40 \pm 0.10 \\
\mathrm{Ww}\end{array}$ & $\begin{array}{c}99.43 \pm 0.69 \\
\mathrm{Ww}\end{array}$ \\
\hline $50 \mathrm{~g} / \mathrm{kg}$ & $\begin{array}{c}89.66 \pm 1.64 \\
X y\end{array}$ & $\begin{array}{c}94.94 \pm 1.09 \\
W x\end{array}$ & $\begin{array}{c}87.01 \pm 0.80 \\
Y y\end{array}$ \\
\hline
\end{tabular}

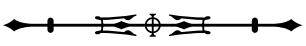




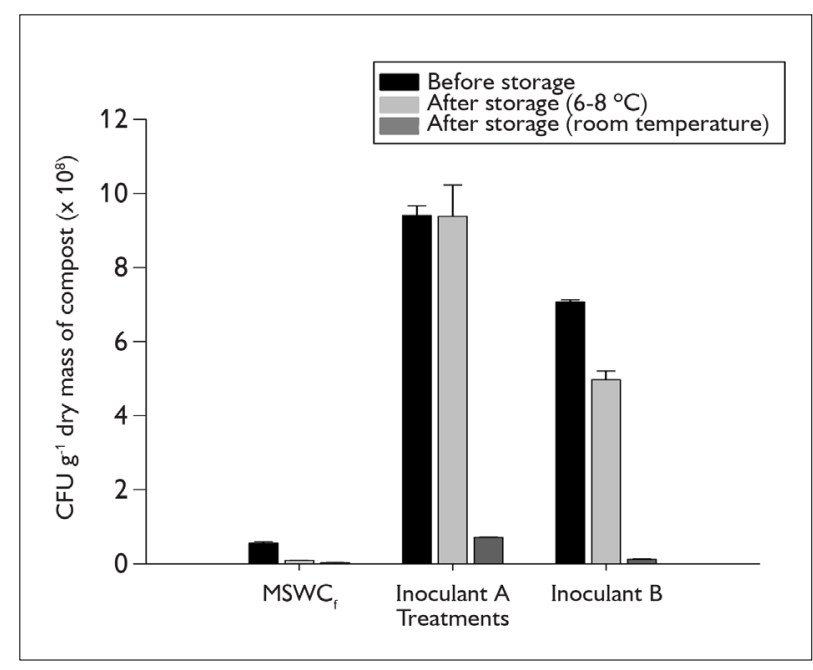

Figure 3. Density of heterotrophic bacteria in inoculants after storage for 97 days at different temperatures. Inoculants A and B were enriched in hydrocarbonoclastic bacteria upon amendment of $\mathrm{N}$ - and P-fertilized MSWC with diesel (50 mL/kg at each application) every $4^{\text {th }}$ (inoculant $A$ ) or $8^{\text {th }}$ day (inoculant B) during 24 days. MSWC received only mineral nutrients at the onset of inoculant production.

The storage temperature influenced $\mathrm{CO}_{2}$ emission only in treatments with inoculant $\mathrm{A}$ (Table 4), with higher $\mathrm{CO}_{2}$ emissions from diesel-contaminated soil inoculated with the inoculant stored under refrigeration. The other treatments showed no significant difference in $\mathrm{CO}_{2}$ emission between the storage temperatures. Inoculated treatments showed higher $\mathrm{CO}_{2}$ emissions than non-inoculated treatment, with no significant difference in $\mathrm{CO}_{2}$ emissions between treatments with inoculants stored at room temperature. In treatments with inoculants stored under refrigeration, $\mathrm{CO}_{2}$ emission from soil inoculated with inoculant $\mathrm{MSWC}_{\mathrm{f}}$ was lower than treatments with inoculants $A$ and $B$.
There was a significant interaction between the type of inoculant and the storage temperature on the degradation of TPH in diesel-contaminated soil. The indigenous populations of the soil used in the experiment were active in the degradation of hydrocarbons (approximately $85 \%$ of TPH biodegradation in the non-inoculated control) (Table 5). However, the inoculation favored TPH biodegradation. Inoculation of the soil with the inoculant A was the most effective, resulting in the highest TPH degradation at both the storage temperatures. There was no effect of temperature of storage on the efficiency of inoculant $\mathrm{A}$. TPH degradation in the treatment with inoculant $A$ stored under room temperature did not differ from that obtained in treatment with inoculant $M_{S W C}$ stored under the same condition (Table 5). Storage of inoculant $B$ at room temperature had a significant negative effect on inoculant efficiency; the opposite was observed with inoculant $\mathrm{MSWC}_{\mathrm{f}}$. The result can be attributed to the differences in the composition of the microbial communities established in the different inoculants.

The highest density of cultivable heterotrophic bacteria was found in soil inoculated with inoculant $\mathrm{MSWC}_{\mathrm{f}}$ stored under refrigeration (Figure 4). Storage under refrigeration resulted in higher population densities of cultivable heterotrophic bacteria in soil than under room temperature for treatments with inoculants $B$ and $M_{S W C}$ For treatments with inoculant $A$, there was no effect of temperature of storage on population densities in soil. The inoculated treatments showed higher densities of heterotrophic bacteria than the non-inoculated control (Figure 4).

Table 4. Cumulative $\mathrm{CO}_{2}$ emission from diesel-contaminated soil $(20 \mathrm{~mL} / \mathrm{kg})$ inoculated with inoculants stored for 97 days under room temperature or refrigeration. The presented data refers to treatments with $30 \mathrm{~g} / \mathrm{kg}$ of the inoculants. Treatment means followed by the same capital letter, in the line, and lowercase letter, in columns (comparison between columns only), do not differ at $5 \%$ probability by Tukey's test. Inoculants A and B were enriched in hydrocarbonoclastic bacteria upon amendment of N-and P-fertilized MSWC with diesel $\left(50 \mathrm{~mL} / \mathrm{kg}\right.$ at each application) every $4^{\text {th }}$ (inoculant A) or $8^{\text {th }}$ day (inoculant B) during 24 days. $M S W C_{f}$ received only mineral nutrients at the onset of inoculant production.

\begin{tabular}{c|c|c|c|c}
\hline Temperature/Treatment & Control & Inoculant A & Inoculant B & MSWC $_{f}$ \\
\hline Room temperature & $163.25 \mathrm{Y}$ & $189.43 \mathrm{WXx}$ & $198.18 \mathrm{WXW}$ & $181.45 \mathrm{XW}_{\mathrm{W}}$ \\
\hline Refrigeration $\left(6-8^{\circ} \mathrm{C}\right)$ & & $200.01 \mathrm{WW}$ & $202.07 \mathrm{WW}$ & $181.12 \mathrm{XW}_{\mathrm{W}}$ \\
\hline
\end{tabular}

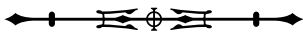


Table 5. Total petroleum hydrocarbon (TPH) degradation in diesel-contaminated soil $(20 \mathrm{~mL} / \mathrm{kg})$ after application of inoculants stored for 97 days at room temperature or under refrigeration. The presented data refers to treatments with $30 \mathrm{~g} / \mathrm{kg}$ of the MSWC or inoculants. Treatment means followed by the same capital letter, in the line, and lowercase letter, in columns (comparison between columns only), do not differ at $5 \%$ probability by Tukey's test. Inoculants A and B were enriched in hydrocarbonoclastic bacteria upon amendment of $\mathrm{N}$ - and P-fertilized MSWC with diesel (50 mL/kg at each application) every $4^{\text {th }}$ (inoculant A) or $8^{\text {th }}$ day (inoculant B) during 24 days. MSWC received only mineral nutrients at the onset of inoculant production.

\begin{tabular}{c|c|c|c|c}
\hline \multirow{2}{*}{ Temperature/Treatment } & \multicolumn{4}{|c}{ TPH degradation (\%) } \\
\cline { 2 - 5 } & Control & Inoculant A & Inoculant B & MSWC $_{f}$ \\
\hline Room temperature & $84.84 \pm 2.14 \times$ & $96.55 \pm 0.66 \mathrm{WW}$ & $66.66 \pm 4.21 \mathrm{Yx}$ & $91.66 \pm 2.13 \mathrm{WXW}$ \\
\hline Refrigeration $\left(6-8^{\circ} \mathrm{C}\right)$ & & $98.14 \pm 0.61 \mathrm{WW}$ & $84.29 \pm 2.42 \mathrm{XW}_{\mathrm{W}}$ & $78.32 \pm 2.98 \times \mathrm{x}$ \\
\hline
\end{tabular}

\section{DISCUSSION}

In this study, we evaluated whether enrichment of hydrocarbonoclastic bacteria in municipal solid waste compost (including non-cultivable populations) can be used for the production of inoculants for application to soils contaminated with hydrocarbons. Application of inoculants resulted in high hydrocarbon biodegradation in diesel-contaminated soil (removal of up to $99.4 \%$ of TPH in only 20 days). In non-inoculated soil, TPH removal was $84.4 \%$ within the same period.

The respiratory activity of the soil was influenced by the type of inoculant added to the soil, but not by the dose of inoculant. However, a significant dose effect of the inoculant was observed on TPH removal, with inhibition of the degradation activity occurring at the highest dose $(50 \mathrm{~g} / \mathrm{kg})$. The conflicting results between the respirometric and TPH analyses can be explained by the use of other sources of organic carbon added as compost (Kuzyakov, 2006), which results in $\mathrm{CO}_{2}$ emissions not originating from hydrocarbon (Dilly, 2001). The negative effect of increasing the dose of inoculants at $>30 \mathrm{~g} / \mathrm{kg}$ on TPH removal is attributed to the adsorption of hydrocarbon molecules to humic fractions present in MSWC, which decreases its bioavailability (Perminova et al., 1999; Leal et al., 2018).

The extended lag phase for $\mathrm{CO}_{2}$ emission observed in non-inoculated soil or in soil inoculated with $\mathrm{MSWC}_{\mathrm{f}}$ (not enriched in hydrocarbonoclastic populations) may indicate the occurrence of toxic effect of diesel on the indigenous

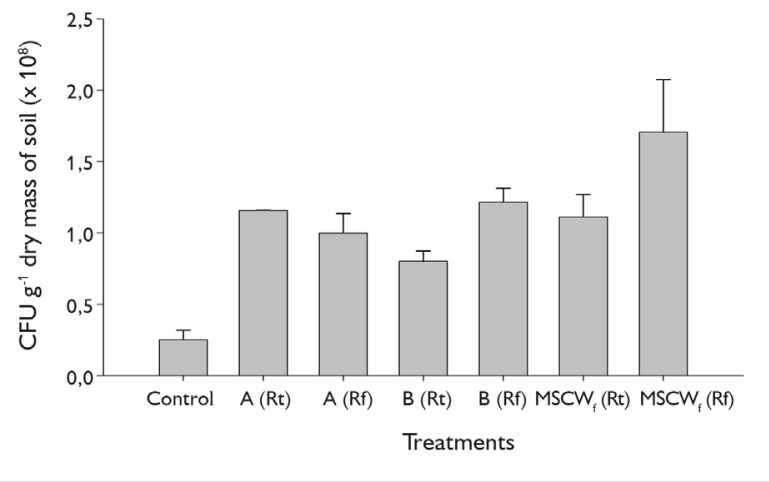

Figure 4. Density of heterotrophic cultivable bacteria in dieselcontaminated soil $(20 \mathrm{~mL} / \mathrm{kg})$ after application of inoculants stored at room temperature (Rt) or under refrigeration (Rf). The presented data refer to treatments with application of $50 \mathrm{~g} / \mathrm{kg}$ of inoculants. Inoculants $\mathrm{A}$ and $\mathrm{B}$ were enriched in hydrocarbonoclastic bacteria upon amendment of $\mathrm{N}$ - and P-fertilized MSWC with diesel $(50 \mathrm{~mL} /$ $\mathrm{kg}$ at each application) every $4^{\text {th }}$ (inoculant A) or $8^{\text {th }}$ day (inoculant B) during 24 days. $M S W C_{f}$ received only mineral nutrients at the onset of inoculant production.

soil microorganisms (Hollender et al., 2003; Labud et al., 2007; Montagnolli et al., 2015) or a low abundance of hydrocarbon-degrading microbial populations. This effect did not occur in soil inoculated with inoculants $A$ and $B$, which were enriched in microbial population adapted/ selected to metabolize hydrocarbons from diesel.

In treatments with inoculants $A$ and $B$, the accumulated $\mathrm{CO}_{2}$ (Figure 1) level was higher as compared to treatment with inoculant $\mathrm{MSWC}_{\mathrm{f}}$ and non-inoculated control during the first $330 \mathrm{~h}$. After this period, a marked increase in $\mathrm{CO}_{2}$ emission was observed in the non-inoculated

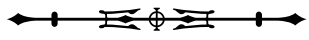


treatment. The result points to a limitation of carbon source in treatments with inoculants $A$ and $B$ after this period, with a possible adaptation of soil microorganisms to diesel as the carbon source. Similar results were reported by Sanni et al. (2015) and Leal et al. (2017), who showed that prior exposure of a microbial community to a contaminant induces physiological adaptations and selection of microbial populations capable of catabolizing the contaminant.

The non-inoculated control showed a much lower population density of cultivable bacteria than treatments with inoculants. Diplock et al. (2009) demonstrated that, in general, soils with low density of cultivable bacteria were associated with low hydrocarbon degradation rates. The soil receiving inoculants consisting only of MSWC enriched with $\mathrm{N}$ and $\mathrm{P}\left(\mathrm{MSWC}_{\mathrm{f}}\right)$ showed higher values of cultivable heterotrophic bacteria. We thus speculate that the lower concentration of diesel present in soil mixed with this inoculant (compared to inoculants $A$ and $B$, which received regular diesel applications) favored the growth of microbial populations, since diesel has a high concentration of light aromatic hydrocarbons, which is toxic to microbial cells (van Dorst et al., 2014). The low molecular weight hydrocarbons induces acute toxic effects on soil microbiota, mostly due to their high solubility and the presence of volatile molecules that can penetrate into cells and alter cellular structures (Du et al., 2012; Harwood et al., 2013; Luo et al., 2014). Another problem of diesel-contaminated soil occurs during the catabolism of aromatic hydrocarbons present in diesel. During the metabolism of aromatic compounds, metabolites with higher toxicity than the parent compounds can build up, such as catechol (Ntougias et al., 2015). Although MSWC does not have microbial populations previously adjusted/selected to use diesel as the carbon source, it has a high microbial diversity and low C:N ratio (Ishii et al., 2000; Namkoong et al., 2002; Wang et al., 2017), which makes it potentially effective to stimulate hydrocarbon biodegradation in diesel-contaminated soil.
In previous studies, the application of a microbial consortium resulted in $57.8 \%$ of TPH removal from diesel-contaminated soil after 55 days (Mariano et al., 2007), while soil bioaugmentation with activated sludge resulted in 66\% removal of TPH from diesel after 45 days (Gallego et al., 2001). Comparison of these results with those achieved in the present study reveals that MSWC-derived inoculants, even $M S W C_{f}$, which did not receive diesel to stimulate the enrichment of hydrocarbonoclastic populations, were much more effective in promoting degradation of hydrocarbons from diesel (> 99\% TPH removal within 20 days at the dose of $30 \mathrm{~g} / \mathrm{kg}$ ) (Table 5). Indigenous soil populations could degrade diesel hydrocarbons, reaching about $85 \%$ of TPH degradation in the same period. These high efficiencies of hydrocarbon degradation, even in the noninoculated soil, can be explained by the manner by which the experiment was conducted. After soil contamination and application of inoculants (or not), the microcosms were coupled to an automatic respirometer, which injected atmospheric air for $5 \mathrm{~min}(500 \mathrm{~mL} / \mathrm{min})$ every $4.5 \mathrm{~h}$. This supposedly prevents oxygen from becoming a limiting factor for the catabolism of hydrocarbons, thereby increasing the efficiency of contaminant biodegradation.

The most important biotic factors for bioaugmentation are predation of allochthonous microorganisms added to the environment as well as the competition between these populations and autochthonous (indigenous) microorganisms (van Veen et al., 1997; Adams et al., 2015). Abiotic factors include the availability of nutrients, oxygen, temperature, water activity, and $\mathrm{pH}$, among others (van Veen et al., 1997; Adams et al., 2015). Thus, for the bioaugmentation strategy to be successful, the introduced microorganisms must possess adaptive advantages beyond the ability to degrade the contaminants in the soil. Our inoculants were effective because they introduce in the contaminated soils a high diversity of microbial populations that constitute the microbial community of MSWC, including non-cultivable microorganisms, thus increasing the probability of successful 
colonization of the new contaminated habitat. The presence of non-cultivable microorganisms in inoculants may also extend the metabolic pathways involved in the degradation of complex contaminants. Zhang et al. (2012) corroborated this statement by reporting that the proportion of physiologically active bacterial populations in soils contaminated with hydrocarbons was greater than that of cultivable populations.

The storage temperature influenced differently the microbial populations in the inoculants. Refrigeration had a positive effect on the maintenance of hydrocarbon biodegradation potential for microbial populations present in the inoculants produced with the addition of diesel (inoculants $\mathrm{A}$ and $\mathrm{B}$ ). For the inoculant consisting of only fertilized MSWC (MSWC $)$, storage at room temperature was more favorable. While it is recognized that refrigeration generally enhances microbial viability, in our study, this was not observed for all the inoculants, possibly due to differences in the structure of the microbial communities. The biodegradation potential of inoculant A after 97 days of storage under refrigeration was found to be identical to that obtained immediately after its production (Table 3 vs. Table 5). High biodegradation potential of this inoculant was also maintained during storage at room temperature. Apparently, frequent exposure to hydrocarbons present in the diesel used for enrichment of hydrocarbonoclastic populations (every 4 days) resulted in the selection of microbial populations tolerant to other environmental stress or, in other words, the induction of cross-resistance mechanisms. This phenomenon of cross-resistance to stress factors in microbial populations has been widely reported (e.g., Fernandes et al., 2003; Gang et al., 2015; Oide et al., 2015; Ramos et al., 2015).

\section{CONCLUSIONS}

The MSWC is an appropriate substrate for developing inoculants for application to hydrocarbon-contaminated soils. The application of inoculants from MSWC to dieselcontaminated soil provided fast and effective removal of hydrocarbon contaminants. The efficiency of inoculant was reduced at dosage $>30 \mathrm{~g} / \mathrm{kg}$ of soil. At lower doses, the use of MSWC along with $N$ and $P$ was found to be efficient for enriching hydrocarbonoclastic microbial populations. When stored for about 100 days, the inoculant produced with the addition of diesel at every 4 days retained its biodegradation potential. We conclude that this strategy is the most recommended for production of inoculant to be used in field scale bioremediation of diesel-contaminated soils.

\section{REFERENCES}

ABED, R. M. M., S. AL-KHARUSI \& M. AL-HINAI, 2015. Effect of biostimulation, temperature and salinity on respiration activities and bacterial community composition in an oil polluted desert soil. International Biodeterioration \& Biodegradation 98: 43-52. DOI: https://doi.org/10.1016/j.ibiod.2014.11.018.

ABURTO-MEDINA, A., E. M. ADETUTU, S. ALEER, J. WEBER, S. S. PATIL, P. J. SHEPPARD, A. S. BALL \& A. L. JUHASZ, 2015. Comparison of indigenous and exogenous microbial populations during slurry phase biodegradation of long-term hydrocarboncontaminated soil. Biodegradation 23(6): 813-822. DOI: http:// dx.doi.org/10.1007/s10532-012-9563-8.

ADAMS, G. O., P. T. FUFEYIM, S. E. OKORO \& I. EHINOMEN, 2015. Bioremediation, biostimulation and bioaugmentation: a review. International Journal of Bioremediation and Biodegradation 3(1): 28-29. DOI: http://dx.doi.org/10.12691/ijebb-3-1-5.

ALLER, S., E. M. ADETUTU, J. WEBER, A. S. BALL \& A. L. JUHASZ, 2014. Potential impact of soil microbial heterogeneity on the persistence of hydrocarbons in contaminated subsurface soils. Journal of Environmental Management 136: 27-36. DOI: http:// dx.doi.org/10.1016/j.jenvman.2014.01.031.

BARUAH, P., R. R. SAIKIA, P. P. BARUAH \& S. KEKA, 2014. Effect of crude oil contamination on the chlorophyll content and morphoanatomy of Cyperus brevifolius (Rottb.) Hassk. Environmental Science and Pollution Research 21(21): 12530-12538. DOI: http://dx.doi. org/10.1007/s11356-014-3195-y.

BENTO, F. M., F. A. O. CAMARGO, B. OKEKE \& W. T. FRANKENBERGER-JÚNIOR, 2003. Bioremediation of soil contaminated by diesel oil. Brazilian Journal of Microbiology 34(supl. 1): 65-68. DOI: http://dx.doi.org/10.1590/S151783822003000500022 .

CHANG, J. S., D. K. CHA, M. RADOSEVICH \& Y. JIN, 2015. Effects of biosurfactants-producing bacteria on biodegradation and transport of phenanthrene in subsurface soil. Journal of Environmental Science and Healthy, Part A 50(6): 611-616. DOI: http://dx.doi.or $\mathrm{g} / 10.1080 / 10934529.2015 .994967$. 
COLLA, T. S., R. ANDREAZZA, F. BUCKER, M. M. SOUZA, L. TRAMONTINI, G. R. PRADO, A. P. FRAZZON, F. A. CAMARGO \& F. M. BENTO, 2014. Bioremediation assessment of diesel-biodieselcontaminated soil using an alternative bioaugmentation strategy. Environmental Science and Pollution Research International 21(4): 2592-2602. DOI: http://dx.doi.org/10.1007/s11356-013-2139-2.

DILLY, O., 2001. Microbial respiratory quotient during basal metabolism and after glucose amendment in soils and litter. Soil Biology and Biochemistry 33(1): 117-127. DOI: https://doi.org/10.1016/S00380717(00)00123-1.

DIPLOCK, E. E., D. P. MARDLIN, K. S. KILHAM \& G. I. PATON, 2009. Predicting bioremediation of hydrocarbons: laboratory of field scale. Environmental Pollution 157(6): 1831-1840. DOI: https:// doi.org/10.1016/j.envpol.2009.01.022.

DU, J., W. T. MEHLER, M. J. LYDY \& J. YOU, 2012. Toxicity of sediment-associated unresolved complex mixture and its impact on bioavailability of polycyclic aromatic hydrocarbons. Journal of Hazardous Materials 203-204: 169-175. DOI: https://doi. org/10.1016/j.jhazmat.2011.11.099.

FANTROUSSI, S. E. \& S. N. AGATHOS, 2005. Is bioaugmentation a feasible strategy for pollutant removal and site remediation? Current Opinion in Microbiology 8(3): 268-275. DOI: https://doi. org/10.1016/j.mib.2005.04.011.

FERNANDES, P., B. S. FERREIRA \& J. M. S. CABRAL, 2003. Solvent tolerance in bactéria: role of efflux pumps and cross-resistance with antibiotics. International Journal Antimicrobial Agents 22(3): 211-216.

GALLEGO, J. L. R., J. LOREDO, J. F. LLAMAS, F. VÁZQUEZ \& J. SÁNCHEZ, 2001. Bioremediation of diesel-contaminated soils: evaluation of potential in situ techniques by study of bacterial degradation. Biodegradation 12(5): 325-335. DOI: https://doi. org/10.1023/A:1014397732435.

GANG, Z., S. QING-SHAN, H. XIAO-MO, X. XIAO-BAO \& C. YIBEN, 2015. Insights into Pseudomonas aeruginosa ATCC9027 resistance to isothiazolones through proteomics. Microbial Drug Resistance 21(2): 140-148. DOI: https://doi.org/10.1089/mdr.2014.0113.

GOGOI, B. K., N. N. DUTTA, P. GOSWAMI \& T. R. K. MOHAN, 2003. A case study of bioremediation of petroleum-hydrocarbon contaminated soil at a crude oil spill site. Advances in Environmental Research 7(4): 767-782. DOI: https://doi.org/10.1016/S10930191(02)00029-1.

GORDON, A., H. D. ZAKPAA \& MAKMENSAH, 2015. Biodegradation potentials of bacterial isolates from petroleum storage facilities within the Kumasi Metropolitan area. African Journal of Microbiology Research 9(7): 433-447. DOI: https://doi.org/10.5897/AJMR2013.6311.

HARWOOD, A. D., P. F. LAUNDRUM \& M. J. LYDY, 2013. Bioavailability-based toxicity endpoints of bifenthrin for Hyalella azteca and Chironomus dilutes. Chemosphere 90(3): 1117-1122. DOI: https://doi.org/10.1016/j.chemosphere.2012.09.017.
HASSANSHAHIAN, M., G. EMTIAZI, G. CARUSO \& S. CAPPELLO, 2014. Bioremediation (bioaugmentation/biostimulation) trials of oil polluted seawater: a mesocosm simulation study. Marine Environmental Research 95: 28-38. DOI: https://doi.org/10.1016/j. marenvres.2013.12.010.

HOLLENDER, J., K. ALTHOFF, M. MUNDT \& W. DORR, 2003. Assessing the microbial activity of soil samples, its nutrient limitation and toxic effects of contaminants using a simple respiration test. Chemosphere 53(3): 269-275. DOI: https://doi.org/10.1016/ S0045-6535(03)00556-3.

ISHII, K., M. FUKUI \& S. TAKII, 2000. Microbial succession during a composting process as evaluated by denaturing gradient gel electrophoresis analysis. Journal of Applied Microbiology 89(5): 768-777. DOI: https://doi.org/10.1046/ j.1365-2672.2000.01177.x.

JÚLIO, A. D. L., R. D. R. FERNANDES, M. D. COSTA, J. C. L. NEVES, E. M. RODRIGUES \& M. R. TÓTOLA, 2018. A new biostimulation approach based on the concept of remaining $P$ for soil bioremediation. Journal of Environmental Management 207: 417-422. DOI: https://doi.org/10.1016/j. jenvman.2017.11.061.

KUZYAKOV, Y., 2006. Sources of $\mathrm{CO}_{2}$ efflux from soil and review of partitioning methods. Soil Biology and Biochemistry 38(3): 425-448. DOI: https://doi.org/10.1016/j. soilbio.2005.08.020.

LABUD, V., C. GARCIA \& T. HERNANDEZ, 2007. Effect of hydrocarbon pollution on the microbial properties of a sandy and a clay soil. Chemosphere 66(10): 1863-1871. DOI: https:// doi.org/10.1016/j.chemosphere.2006.08.021.

LEAL, A. J., E. M. RODRIGUES, P. L. LEAL, A. D. L. JÚLIO, R. C. R. FERNANDES, A. C. BORGES \& M. R. TÓTOLA, 2017. Changes in the microbial community during bioremediation of gasolinecontaminated soil. Brazilian Journal of Microbiology 48(2): 342-351. DOI: http://dx.doi.org/10.1016/j.bjm.2016.10.018.

LEAL, A. J., E. M. RODRIGUES, R. C. R. FERNANDES, A. C. BORGES, A. D. L. JÚLIO, F. S. FREITAS \& M. R. TÓTOLA, 2018. Microbial inoculants development for bioremediation of gasoline and diesel contaminated soil. Open Access Library Journal 5(4): 1-17. DOI: http://dx.doi.org/10.4236/oalib.1104449.

LIN, Q. \& I. A. MENDELSSOHN, 2012. Impacts and recovery of the Deepwater Horizon oil spill on vegetation structure and function of coastal salt marshes in the northern Gulf of Mexico. Environmental Science and Technology 46(7): 3737-3743. DOI: http://dx.doi.org/10.1021/es203552p.

LUO, W., R. A. VERWEIJ \& C. A. M. GESTEL, 2014. Determining the bioavailability and toxicity of lead contamination to earthworms requires using a combination of physicochemical and biological methods. Environmental Pollution 185: 1-9. DOI: http://dx.doi. org/10.1016/j.envpol.2013.10.017.

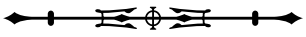


MAO, X., R. JIANG, W. XIAO \& J. YU, 2015. Use of surfactants for the remediation of contaminated soils: a review. Journal of Hazardous Materials 285: 419-435. DOI: https://doi.org/10.1016/j. jhazmat.2014.12.009.

MARIANO, A. P., A. P. A. G. KATAOKA, D. F. ANGELIS \& D. M. BONOTTO, 2007. Laboratory study on the bioremediation of diesel oil contaminated soil from a petrol station. Brazilian Journal of Microbiology 38(2): 346-353. DOI: http://dx.doi.org/10.1590/ S1517-83822007000200030.

MINAI-TEHRANI, D., P. ROHANIFAR \& S. AZAMI, 2015. Assessment of bioremediation of aliphatic, aromatic, resin, and asphaltene fractions of oil-sludge-contaminated soil. International Journal of Environmental Science and Technology 12(4): 12531260. DOI: https://doi.org/10.1007/s13762-014-0720-y.

MONTAGNOLLI, R. N., P. R. M. LOPES \& E. D. BIDOIA, 2015. Screening the toxicity and biodegradability of petroleum hydrocarbons by a rapid colorimetric method. Archives of Environmental Contamination and Toxicology 68(2): 342-353. DOI: https://doi.org/10.1007/s00244-014-0112-9.

MOSAED, H. P., S. SOBHANARDAKANI, H. MERRIKHPOUR, A. FARMANY, M. CHERAGHI \& S. ASHORLO, 2015. The effect of urban fuel stations on soil contamination with petroleum hydrocarbons. Iranian Journal of Toxicology 9(30): 1378-1384.

NAMKOONG, W., E. Y. HWANG, J. S. PARK \& J. Y. CHOI, 2002. Bioremediation of diesel-contaminated soil with composting. Environmental Pollution 119(1): 23-31. DOI: https://doi.org/10.1016/ S0269-7491(01)00328-1.

NTOUGIAS, S., P. MELIDIS, E. NAVROZIDOU \& F. TZEGKAS, 2015. Diversity and efficiency of anthracene-degrading bacteria isolated from a denitrifying activated sludge system treating municipal wastewater. International Biodeterioration \& Biodegradation 97: 151-158. DOI: https://doi.org/10.1016/j.ibiod.2014.11.009.

OIDE, S., W. GUNJI, Y. MOTEKI, S. YAMAMOTO, M. SUDA, T. JOJIMA, H. YUKAWA \& M. INUI, 2015. Thermal and solvent stress cross-tolerance conferred to Corynebacterium glutamicum by adaptative laboratory evolution. Applied and Environmental Microbiology 81: 2284-2298. DOI: https://doi.org/10.1128/ AEM.03973-14.

PERMINOVA, I. V., N. Y. GRECHISHCHEVA \& V. S. PETROSYAN, 1999. Relationships between structure and binding affinity of humic substances for polycyclic aromatic hydrocarbons: relevance of molecular descriptors. Environmental Science and Technology 33(21): 3781-3787. DOI: https://doi.org/10.1021/es990056x.

RAMOS, J. L., M. S. CUENCA, C. MOLINA-SANTIAGO, A. SEGURA, E. DUQUE, M. R. GÓMEZ-GARCÍA, Z. UDAONDO \& A. ROCA, 2015. Mechanisms of solvent resistance mediated by interplay of cellular factors in Pseudomonas putida. FEMS Microbiology Reviews 39(4): 555-566. DOI: https://doi. org/10.1093/femsre/fuv006.
RODRIGUES, E. M., K. H. M. KALKS, P. L. FERNANDES \& M. R. TÓTOLA, 2015a. Bioremediation strategies of hydrocarbons and microbial diversity in the Trindade Island shoreline - Brazil. Marine Pollution Bulletin 101(2): 517-525. DOI: http://dx.doi.org/10.1016/j. marpolbul.2015.10.063.

RODRIGUES, E. M., K. H. M. KALKS \& M. R. TÓTOLA, $2015 b$. Prospect, isolation, and characterization of microorganisms for potential use in cases of oil bioremediation along the coast of Trindade Island, Brazil. Journal of Environmental Management 156: 15-22. DOI: http://dx.doi.org/10.1016/j.jenvman.2015.03.016.

RODRIGUES, E. M. \& M. R. TÓTOLA, 2015. Petroleum: from basic features to hydrocarbons bioremediation in oceans. Open Access Library Journal 2(11): 1-17. DOI: http://dx.doi.org/10.4236/oalib.1102136.

ROLING, W. F. M., M. G. MILNER, D. M. JONES, K. LEE, F. DANIEL, R. J. P. SWANNELL \& I. M. HEAD, 2002. Robust hydrocarbon degradation and dynamics of bacterial communities during nutrient-enhanced oil spill bioremediation. Applied and Environmental Microbiology 68(11): 5537-5548. DOI: http:// dx.doi.org/10.1128/aem.68.11.5537-5548.2002.

RUBERTO, L., R. DIAS, B. A. LO, S. C. VAZQUEZ, E. A. HERNANDEZ \& W. P. MAC CORMACK, 2009. Influence of nutrients addition and bioaugmentation on the hydrocarbon biodegradation of a chronically contaminated Antarctic soil. Journal of Applied Microbiology 106(4): 1101-1110. DOI: http://dx.doi. org/10.1111/j.1365-2672.2008.04073.x.

SANNI, G. O., F. COULON \& T. J. MCGENITY, 2015. Dynamics and distribution of bacterial and archaeal communities in oil-contaminated temperate coastal mudflat mesocosms. Environmental Science and Pollution Research 22(20): 15230-15247. DOI: http://dx.doi. org/10.1007/s11356-015-4313-1.

STRAUBE, W. L., J. JONES-MEEHAN, P. H. PRITCHARD \& W. R. JONES, 1999. Bench-scale optimization of bioaugmentation strategies for treatment of soils contaminated with high molecular weight polyaromatic hydrocarbons. Resources, Conservation and Recycling 27(1-2): 27-37. DOI: https://doi.org/10.1016/S09213449(98)00083-4.

STROUD, J. L., G. I. PATON \& K. T. SEMPLE, 2007. Microbe-aliphatic hydrocarbon interactions in soil: implications for biodegradation and bioremediation. Journal of Applied Microbiology 102(5): 12391253. DOI: https://doi.org/10.1111/J.1365-2672.2007.03401.x.

SUN, J., L. PAN, D. C. W. TSANG, Y. ZHAN, L. ZHU \& X. LI, 2018. Organic contamination and remediation in the agricultural soils of China: a critical review. Science of the Total Environment 615: 724-740. DOI: https://doi.org/10.1016/j.scitotenv.2017.09.271.

SUTTON, N. B., F. MAPHOSA, J. Á. MORILLO, W. ABU AL-SOUD, A. A. LANGENHOFF, T. GROTENHUIS, H. H. RIJNAARTS \& $H$. SMIDT, 2013. Impact of long-term diesel contamination on soil microbial community structure. Applied and Environmental Microbiology 79(2): 619-630. DOI: http://dx.doi.org/10.1128/AEM.02747-12.

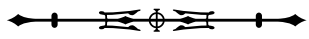


UNITED STATES ENVIRONMENTAL PROTECTION AGENCY (USEPA), 1996. Method 9074: Turbidimetric screening method for total recoverable petroleum hydrocarbons in soil. Government Printing Office, Washington.

VAN DORST, J., S. D. SICILIANO, T. WINSLEY, I. SNAPE \& B. C. FERRARI, 2014. Bacterial targets as potential indicators of diesel fuel toxicity in subantartic soils. Applied and Environmental Microbiology 80(13): 4021-4033. DOI: http://dx.doi.org/10.1128/ AEM.03939-13.

VAN VEEN, J. A., L. S. VAN OVERBEEK \& J. D. VAN ELSAS, 1997. Fate and activity of microorganisms introduced into soil. Microbiology and Molecular Biology Reviews 61(2): 121-135.

VIEIRA, P. A., R. B. VIEIRA, F. P. FRANÇA \& V. L. CARDOSO, 2007. Biodegradation of effluent contaminated with diesel fuel and gasoline. Journal of Hazardous Materials 140(1-2): 52-59. DOI: http://dx.doi. org/10.1016/j.jhazmat.2006.06.048.
VOGEL, T. M., 1996. Bioaugmentation as a soil bioremediation approach. Current Opinion in Biotechnology 7(3): 311-316. DOI: https://doi.org/10.1016/S0958-1669(96)80036-X.

WANG, X., A. CAO, G. ZHAO, C. ZHOU \& R. XU, 2017. Microbial community structure and diversity in a municipal solid waste landfill. Waste Management 66: 79-87. DOI: https://doi.org/10.1016/j. wasman.2017.04.023.

WU, Y., Y. LUO, D. ZOU, J. NI, W. LIU, Y. TENG \& Z. LI, 2008. Bioremediation of polycyclic aromatic hydrocarbons contaminated soil with Monilinia sp.: degradation and microbial community analysis. Biodegradation 19(2): 247-257. DOI: https://doi.org/10.1007/ s10532-007-9131-9.

ZHANG, D. C., C. MORTELMAIER \& R. MARGESIN, 2012. Characterization of the bacterial archaeal diversity in hydrocarboncontaminated soil. Science of the Total Environment 421-422: 184196. DOI: https://doi.org/10.1016/j.scitotenv.2012.01.043. 